.

\title{
“印度洋与青藏高原的相互作用”主题论坛概述
}

张经 ${ }^{1,2 *}$, 姚檀栋 ${ }^{3}$

1. 上海交通大学海洋学院, 上海 200030;

2. 华东师范大学河口海岸学国家重点实验室, 上海 200241 ;

3. 中国科学院青藏高原研究所, 北京 100101

* 联系人, E-mail: jzhang@sklec.ecnu.edu.cn

\section{Overview of the Forum on Interactions between Indian Ocean and Tibetan Plateau}

\author{
Jing Zhang ${ }^{1,2^{*}} \&$ Tandong Yao ${ }^{3}$ \\ ${ }^{1}$ School of Oceanography, Shanghai Jiaotong University, Shanghai 200030, China; \\ ${ }^{2}$ State Key Laboratory of Estuarine and Coastal Research, East China Normal University, Shanghai 200241, China; \\ ${ }^{3}$ Institute of Tibetan Plateau Research, Chinese Academy of Sciences, Beijing 100101, China \\ * Corresponding author, E-mail: jzhang@sklec.ecnu.edu.cn
}

doi: $10.1360 /$ TB-2020-1526

由中国科学院学部主办、中国科学院地学部常委会、 学部学术与出版工作委员会承办的第108次“科学与技术前 沿论坛”于2020年10月26 27日在上海举行. 在新冠肺炎疫情 期间, 论坛采取了线上(网络)和线下(现场)结合的方式. 中国 科学院、中国工程院、国家自然科学基金委员会、国内高 校、科研机构的专家、学者、管理人员等约 300 人参加本次 论坛. 其中, 有 200 多位国内外的学者和学生在线上注册参加 了会议. 据统计, 此次论坛期间, 采取线上参会的学术同行达 到 510 人次. 此次论坛的主题是: 印度洋与青藏高原的相互作 用. 期间，与会者就印度洋-青藏高原地区的大气、冰川、海 洋与地表水、生物区系、大地构造等不同圈层之间的相互 作用开展了多方位的学术交流, 并以此为切人点为今后地球 系统科学的发展献计献策.

\section{1 从不同的学科视野分析和认识印度洋与青 藏高原的相互作用}

印度洋与青藏高原相互作用的影响范围覆盖了地球表 面中低纬度地区超过 $1 / 3$ 的面积, 并且形成了世界上最为独特 的季风气候. 在这个地区, 分布着占有世界大约一半的人口. 当地社会的可持续发展，特别是在粮食、水资源的供给，贸 易和航运安全等方面也受到印度洋与青藏高原相互作用的 制约. 据历史学家与社会学家的研究结果, 在这一区域数千 年的社会演化中, 诞生和演绎着包括古埃及、希腊、罗马、 波斯、穆斯林、印度、东非斯瓦希里、基督教和华夏等不
同文明的交融和更迭. 在“构建人类命运共同体”的国家战略 中, 印度洋与青藏高原的相互作用和影响的研究既是国际科 学进步的前沿问题, 也是社会发展中的现实问题.

本次论坛设立了青藏高原的大气、地表过程与全球变 化、印度洋的物理过程与气候、印度洋的生物地球化学过 程与生态系统等3个专题, 并且利用半天的时间对会上聚焦 的科学问题与今后实施的想法进行归纳和总结. 本次论坛邀 请了国内地球科学领域的 9 位专家作了主旨和引导性的报告 (https://mp.weixin.qq.com/s/9y5XtjG-tTUIa4nUoMmOqA). 他 们是中国科学院大气物理研究所的吴国雄院士、中国科学 院青藏高原研究所的姚檀栋院士、中国科学院南海海洋研 究所中斯联合科教中心/中山大学的王东晓教授、中国科学 院海洋研究所的袁东亮研究员、上海交通大学的周否教 授、中国科学院南海海洋研究所的向荣和张兰兰研究员、 中国科学院海洋研究所的张武昌研究员、上海交通大学/华 东师范大学的张经院士. 报告的内容聚焦在青藏高原的地貌 与植被演化、季风与气候、印度洋的物理与生物地球化学 过程、生态系统的结构、环境变化的记录等多维视角, 并且 跨越了不同的时间和空间尺度.

\section{2 以印度洋与青藏高原的相互作用作为切入 点, 推动地球系统科学的发展}

与会的专家和学者认为, 今后应大力推动印度洋与青藏 高原之间相互作用领域的整合研究, 包括陆-海-气一体的观 
测和相应的技术革新, 并以此为切人点推动地球系统科学向 纵深发展. 本次论坛提出了如下具有建设性的意见.

(1) 印度洋与青藏高原的相互作用不应该仅仅认为是气 候变化的问题. 这个地区自然灾害频发和聚集，存在着跨境 水资源和污染物输运、国际渔业捕捞配给和海底资源主张 等诸多方面的地缘政治诉求，与实现国家的“人类命运共同 体”的战略息息相关.

(2) 针对印度洋与青藏高原相互作用的研究宜以水、能 量循环为主线. 通过水与能量循环, 将大气、地理、古环 境、生态、海洋等不同的学科相互结合起来. 在实施中, 需 要着手建立陆地与海洋相互配套的观测计划和断面.

(3) 季风变化是认识印度洋与青藏高原相互作用的切人 点. 季风体现着高原、大气和海洋之间的相互作用. 在更长 的时间尺度上，上述三者之间的相互关系还受到南半球的制 约. 有证据表明, 印度洋南部的“马斯克林”高压产生的影响在 黄土高原中都存在着记录.

(4) 印度洋与青藏高原相互作用的研究应同国家战略结 合．这个地区影响着亚洲、非洲和欧洲之间的贸易和物资交 流, 对国家的安全与可持续发展至关重要. 科学研究应该与
实施国家的战略结合，包括资源、航运、食品安全、自然灾 害等不同方面, 并形成一个咨询报告.

(5) 重视印度洋与青藏高原的相互作用在地球系统科学 中的独特地位. 在印度洋与青藏高原的相互作用系统中, 前 者通过对季风、水汽输送、能量的影响制约着高原，后者通 过制约流场、温度、初级生产力、人海径流等方面反馈于 印度洋.

（6）理解印度洋与青藏高原的相互作用需要提升区域性 的国际合作. 深化这一地区的学术活动, 仰仗于一个广泛、 持久和多方位的国际合作网络. 在这一地区，存在着不同种 族、文化与宗教的相互融合，地缘政治的博峦非常地复杂， 许多的研究问题都是跨境的.

\section{3 学术活动产生了广泛的影响}

参加本次论坛的专家和学者具有专业分布广、年龄结 构宽的特点, 其中还包括年轻的硕士、博士研究生. 会上, 一 些年轻的学者通过线上留言的方式提问、回答问题. 与会者 还包括一些来自国外的同行，在线上讨论时也涉及其他国家 目前在印度洋与青藏高原地区进行的研究项目. 